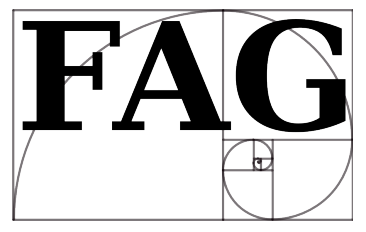

http://www.nauka-a-religia.uz.zgora.pl/images/FAG/2007-2008.t.4-5/art.10.pdf

\author{
Justyna Kroczak *
}

\title{
Mivart i granice ewolucji ${ }^{* *}$
}

St. George Jackson Mivart (1827-1900) ${ }^{1}$ urodził się w Londynie. Edukację rozpoczął w Clapham Grammar School, a kontynuował w Harrow, londyńskim King's College oraz w St. Mary's College w Oscott. Za młodu interesował się architekturą, co stało się powodem, że w wieku szesnastu lat odbył wycieczkę do neogotyckich świątyń zaprojektowanych przez Pugina. ${ }^{2}$ Zwiedzając katedrę św. Chada w Birmingham spotkał dra Johna Moore'a (późniejszego przewodniczącego St. Mary's College w Oscott), pod wpływem którego nawrócił się na katolicyzm w 1844 r. Konwersja jednak uniemożliwiła mu rozpoczęcie studiów na Oksfordzie, bowiem tam przyjmowano tylko studentów wyznania anglikańskiego. W związku z tym kontynuował naukę w szkole medycznej przy szpitalu St. Mary, którą ukończył w 1846 r. W styczniu tego samego roku rozpoczął studia w Lincoln's Inn. W 1862 r. został mianowany wykładowcą anatomii porównawczej w szkole medycznej przy szpitalu St. Mary, którą sam niegdyś ukończył. Dwanaście lat później stał się profesorem biologii w Katolickim University College w Kensington. Związany był także z Uni-

* Studentka Instytutu Filozofii Uniwersytetu Zielonogórskiego.

** Recenzent: Piotr Lenartowicz SJ, Katedra Filozofii Przyrody Wydziału Filozoficznego Wyższej Szkoły Filozoficzno-Pedagogiczej Ignatianum w Krakowie.

${ }^{1}$ Podstawową biografią Mivarta jest J.W. Grubera A Consciousness in Conflict: The Life of St. George Jackson Mivart, Columbia University Press, Nowy Jork 1960. wnętrz.

${ }^{2}$ Augustus Welby Northmore Pugin (1812-1852) - angielski architekt i projektant 
wersytetem Lowańskim, gdzie prowadził wykłady z filozofii przyrodoznawstwa. Brał czynny udział w życiu kulturalno-naukowym Anglii, co przejawiało się m.in. w jego członkostwie w licznych towarzystwach naukowych. Od 1849 r. był członkiem Instytucji Królewskiej (Royal Institution), a od 1862 r. - członkiem Towarzystwa im. K. Linneusza (Linnean Society). Niedługo potem, bo w 1869 r., został członkiem Towarzystwa Zoologicznego (Zoological Society). W r. 1867 wyróżniono go powołaniem do Royal Society na podstawie pracy „On the Appendicular Skeleton of the Primates" (O szkielecie kończyn naczelnych) przedstawionej Towarzystwu przez Huxleya. ${ }^{3}$ Uznana została za niezwykle wartościową. Mivart był też od 1874 r. członkiem Towarzystwa Metafizycznego. Jeśli idzie natomiast o jego karierę uniwersytecką, to stopień doktora filozofii otrzymał on od papieża Piusa IX w 1876 r., a stopień doktora medycyny uzyskał w 1884 r. na Uniwersytecie Lowańskim. Przez całe życie wiele pisał, zarówno prace naukowe, jak i publicystykę, tak dla czasopism brytyjskich, jak i amerykańskich. Dla Encyklopedii Brytyjskiej opracował hasło „małpa”.

W 1871 r. opublikował pracę On the Genesis of Species [O pochodzeniu gatunków], którą anonsował Quarterly Review. Dzięki poglądom w niej zawartym znalazł się, wspólnie z Karolem Darwinem i jego zwolennikami, w centrum uwagi intelektualnego świata Anglii. W dziele tym krytykował jeden z aspektów Darwinowskiej teorii ewolucji - mechanizm doboru naturalnego - co poróżniło go zarówno z samym zainteresowanym, jak jego zagorzałym stronnikiem, T.H. Huxleyem. Mimo wszystko, reputacja Mivarta jako biologa bynajmniej nie ucierpiała. Co prawda, zgadzał się z teorią makroewolucji, ale równocześnie podkreślał nieprzekraczalną różnicę pomiędzy tym, co nieożywione, a tym, co ożywione, między tym, co czysto zwierzęce, a tym, co racjonalne.

Dla darwinistów było to trudne do przyjęcia, bowiem ta doktryna ewolucjonistyczna, pozbawiona kluczowego elementu doboru natural-

\footnotetext{
${ }^{3}$ Thomas Henry Huxley (1825-1895) - angielski biolog i ewolucjonista, przyjaciel Darwina.
} 
nego, stałaby się bezwartościowa. Tymczasem Mivart usiłował pogodzić ewolucjonizm z wiarą katolicką przez propagowanie w swoich pismach kreacjonistycznej teorii początków duszy ludzkiej. Odrzucił ewolucyjną wersję genezy ludzkiego umysłu. Poglądy na relację między intelektem, naturą ludzką a naturą zwierzęcą przedstawił w Nature and Thought [Przyroda i myśl] (1882) oraz w Origin of Human Reason [Geneza rozumu ludzkiego] (1889). Rozważał tam i wyjaśniał fundamentalne różnice między człowiekiem a zwierzęciem.

W r. 1873 opublikował Lessons in Elementary Anatomy [Lekcje z anatomii elementarnej] oraz esej „Man and Apes” [Człowiek i małpy]. W 1881 r. wydał pracę zoologiczną The Cat: An Introduction to the Study of Back-Boned Animals [Kot. Wprowadzenie do badań nad kręgowcami], która, dzięki swojej szczegółowości i przejrzystości, została uznana za dorównującą pracy T.H. Huxleya The Crayfish: An Introduction to the Study of Zoology [Raki. Wprowadzenie do badań zoologicznych] (1879). Wiele wysiłku włożył w badania nad ssakami owadożernymi (Insectivora) i mięsożernymi (Carnivora). Wzbogacił przez to znacznie wiedzę o anatomii tych grup.

Ze wspomnianym już Huxleyem po raz pierwszy spotkał się w 1859 r. Mivart słuchał jego wykładów i na początku swojej kariery naukowej niewątpliwie znajdował się pod jego wpływem. Huxley, który był wrogiem katolicyzmu, krytykował pracę Mivarta On the Genesis of Species, z powodu zawartej w niej tezy o boskim pochodzeniu duszy człowieka. Z kolei Darwin określił autora jako „wybitnie niesprawiedliwego". Konflikt osiągnął apogeum, gdy Mivart napisał wrogą recenzję książki Darwina O pochodzeniu czlowieka (1871) w Quarterly Review. ${ }^{4}$

Mivart, jak już zaznaczyliśmy, był ewolucjonistą, lecz pomniejszał udział doboru naturalnego w procesie rozwoju. Sądził bowiem, że specjacja zachodzi za przyczyną wrodzonej, twórczej zdolności, zwanej

\footnotetext{
${ }^{4}$ Por. St. George Jackson Mivart, „The Descent of Man”, w: St. George Jackson Mivart, Essays and Criticisms, vol. II, Little Brown and Company, Boston 1892.
} 
przezeń indywidualizacją (individuation). ${ }^{5} \mathrm{~W}$ tym, rzecz jasna, zbliżał się do lamarckistów. W On Truth pisał, że zasada indywidualizacji jest formą ciała materialnego. Ciało i jego forma to jedno, tak jak wosk i odbita na nim pieczęć. ${ }^{6}$ Zasada indywidualizacji to nic innego jak forma substancjalna w znaczeniu Arystotelesowskim, czyli po prostu ożywiająca ciało dusza. Podobnie w On the Genesis of Species Mivart czynił ją, nie zaś dobór naturalny, odpowiedzialną za rozwój i specjację form organicznych. ${ }^{7}$ Dobór naturalny nigdy nie mógłby wytworzyć złożonych struktur biologicznych, jak oko kręgowców, ponieważ wtedy początkowe stadia struktury mogły być nieprzydatne, a więc nie ostałyby się $\mathrm{w}$ procesie doboru naturalnego.

Mivart zaprzeczał przede wszystkim ewolucji intelektu ludzkiego, podkreślał, że powstał on dzięki mocy Boskiej. Wyklęty przez ewolucjonistów angielskich, Mivart z czasem stracił także względy Kościoła. Podczas swojej profesury na Uniwersytecie Lowańskim, gdzie w latach 1890-1893 wykładał filozofię przyrodoznawstwa, opublikował serię artykułów w Nineteenth Century. Opowiadał się w nich za prawdziwością twierdzeń nauki, nawet tych sprzecznych z dogmatami religii. Spekulacja Mivarta zbliżała się do sui generis interpretacji dogmatów, która pozostawała $\mathrm{w}$ niezgodzie $\mathrm{z}$ oficjalną wiarą. Stanowisko Mivarta było właściwie herezją. Publikacje te zostały umieszczone na watykańskim indeksie ksiąg zakazanych (Index Expurgatorius). Wśród nich znalazły się: „Modern Catholics and Scientific Freedom” (1885), „Sins of Belief and Disbelief” (1888), „The Catholic Church and Biblical Criticism” (1887), „Catholicity and Reason” (1887), „Happiness in Hell” (1892). Dalsza jego działalność publicystyczna, utrzymana w tym samym, wrogim Kościołowi tonie, a w szczególno-

${ }^{5}$ St. George Jackson Mivart, The Origin of Human Reason, Kegan Paul, Trench \& Co., London 1889, s. 73; St. George Jackson Mivart, On Truth, Kegan Paul, Trench \& Co., London 1889, s. 422-424; St. George Jackson Mivart, On the Genesis of Species, MacMillan \& Co., London 1871, s. 210, 259-261, 313.

${ }^{6}$ Mivart, On Truth..., s. 423.

${ }^{7}$ Por. Mivart, On the Genesis of Species..., s. 210. 
ści dwa artykuły: „The Continuity of Catholicism” (Nineteenth Century, styczeń 1900) oraz „Some Recent Apologists” (Fortnightly Review, styczeń 1900), sprowokowały najpierw napomnienie (monitio canonica), a w końcu doprowadziła do obłożenia go ekskomuniką przez kard. Vaughana (18 stycznia 1900). Mivart ogłosił swoją korespondencję z arcybiskupem w Timesie (27 stycznia 1900). W Nineteenth Century z marca 1900 r. ukazał się jeszcze artykuł „Scripture and Roman Catholicism". ${ }^{8}$

Krótko potem, 1 kwietnia 1900 r., Mivart zmarł w Londynie na cukrzycę. Ze względu na ekskomunikę pochowany został bez jakiegokolwiek obrządku kościelnego. Jego przyjaciele, zatroskani tym faktem, próbowali przekonać władze kościelne, że powaga i natura choroby, na którą cierpiał Mivart, w pełni tłumaczyła jego zaskakującą niekonsekwencję w określeniu swojego ostatecznego stanowiska w sprawie wiary. To choroba miała stanowić przyczynę tak nieortodoksyjnych poglądów. Starania przyjaciół odniosły zamierzony skutek i 18 stycznia 1904 r. na cmentarzu Kensal Green odprawiono za niego katolickie rytuały pogrzebowe.

Mivart był uczonym - biologiem i filozofem, angażującym się w ówczesne problemy nauki i - związane $\mathrm{z}$ tą nauką - problemy wiary. Niewątpliwie, takim pierwszoplanowym problemem w naukach przyrodniczych, swoistym signum temporis drugiej połowy XIX w., była wówczas kwestia ewolucji darwinowskiej. Najbardziej kontrowersyjna praca Mivarta, On the Genesis of Species (1871) bezpośrednio się do niej odnosiła. Stanowiła krytyczny komentarz do pewnych aspektów teorii Darwina, zawartej w dziele O powstawaniu gatunków
\end{abstract}

\footnotetext{
${ }^{8}$ Por. Under the Ban. A Scientist's Heresies Condemned by the Church. A Correspondence between Dr. St. George Mivart and Cardinal Vaughan, The Tucker Publishing, New York 1900. Mivart został wezwany do wyznania wiary, wedle formuły podanej przez arcybiskupa (zamieszczono ją w cytowanej publikacji).
} 
drogą doboru naturalnego (1859). Jak zaznaczyliśmy, Mivart kwestionował zastosowanie mechanizmu doboru naturalnego do wyjaśnienia powstania umysłu ludzkiego, choć akceptował ideę makroewolucji. Kazimierz Jodkowski pisze:

Mivart argumentował, że dobór naturalny nie jest w stanie wyprodukować nowych odmian, ale że zmiany ewolucyjne zachodzą we względnie dużych krokach, oraz że dobór naturalny nie może wyjaśnić pochodzenia gatunków [...] Akceptował pojęcie ewolucji, ale odrzucał rozumowanie Darwina w tej sprawie i wskazywał na wiele niespójności w różnych wydaniach książki Darwina [...]. ${ }^{9}$

Pod wpływem tych uwag Darwin dokonał zmian redakcyjnych i odpowiedział na zarzuty Mivarta. ${ }^{10}$

Pogląd, jakoby umysł ludzki nie dawał się sprowadzić do jakiegokolwiek zjawiska naturalnego, Mivart uzasadniał różnicami między konstytucją psychiczną człowieka i zwierząt. Opisaniu i wythumaczeniu tych różnic został poświęcony esej „A Limit to Evolution”. ${ }^{11} \mathrm{Za}-$ sadniczym zamysłem publikacji była próba udowodnienia nieprzekraczalności granicy między istotą ludzką a niższymi zwierzętami. Granica ta, stanowiąca zarazem fundamentalną różnicę, zawiera się, zdaniem Mivarta, nie w ciele, ale w umyśle człowieka. Punktem wyjścia było wypunktowanie i opisanie różnych zdolności ludzkich. Człowiek posiada zatem zdolność odczuwania, czyli zdolność chęci i pragnienia, oraz zdolność dostrzegania takich wrażeń jak kolory, dźwięki czy od-

\footnotetext{
${ }^{9}$ Kazimierz JoDKowski, Metodologiczne aspekty kontrowersji ewolucjonizm-kreacjonizm, Realizm. Racjonalność. Relatywizm, t. 35, Wydawnictwo UMCS, Lublin 1998, s. 146.

${ }^{10}$ Darwin powołuje się na Mivarta w następujących miejscach O powstawaniu gatunków: rozdz. V. Prawo zmienności, „Zmienność korelacyjna”, s. 146; VI. Trudności teorii, „Szczególne trudności, które napotyka teoria doboru naturalnego”, s. 189; VII. Rozmaite zarzuty, s. 216-248; XIV. Pokrewieństwo wzajemne istot organicznych..., „Podobieństwa analogiczne", s. 449. Podajemy wg wydania: O powstawaniu gatunków drogą doboru naturalnego, przeł. Szymon Dickstein \& al., PWRiL, Warszawa 1955.

${ }^{11}$ Por. St. George Jackson Mivart, „A Limit to Evolution”, w: Mivart, Essays and Criticisms...
} 
czucie gorzkości. Posiada on również zdolność pamięci. Istotniejsze jest jednak to, że wszystkie te doznania i wrażenia łączymy w grupy, a następnie $w$ grupy tych grup. W praktyce oznacza to tyle, że jedno wrażenie wywołuje serię następnych, na przykład dźwięk otwieranej parasolki powoduje $\mathrm{w}$ nas pojawienie się przeczucia zbliżającego się deszczu.

Wspomniane grupy odczuć nie są jednorodne i odpowiednio noszą własne nazwy. Mivart wyróżnia wśród nich dwie grupy: (1) percepcję zmysłową, która towarzyszy percepcji intelektualnej rzeczy zewnętrznych i (2) wnioskowanie zmysłowe, które pobudza tzw. odczucia oczekujące (np. doznanie jasnego błysku światła powstało dzięki takiemu połączeniu odczuć, które prowadzi do oczekiwanego odczucia trzasku pioruna).

Powyższe informacje miały pomóc Mivartowi odpowiedzieć na jedno $\mathrm{z}$ ważnych pytań: $\mathrm{w}$ jaki sposób postrzegamy i czym właściwie jest percepcja? Bowiem to właśnie w percepcji ludzkiej jest coś, czego nie ma w percepcji zwierzęcej. Analizując to pytanie, autor przechodzi do właściwej części eseju. Mivart zauważył, że aby cokolwiek spostrzec i zidentyfikować to jako „,coś”, musimy posiadać w umyśle „ideę bycia”. Idea ta sama w sobie jest niewythumaczalna, ale jej ukryte implikacje mogą zostać poznane. Co więcej, jawi się ona odpowiednią do opisania wszystkiego, co może być pojęte przez umysł ludzki. Każde odczucie stanowi modyfikację odczucia bycia. Zatem, odczucie istnienia jest tak fundamentalne, że bez jego posiadania nic nie moglibyśmy spostrzec ani zrozumieć. Aby pojąć jakąś rzecz, musimy pojąć, czym ta rzecz jest - musimy posiadać pojęcie istoty (whatness). To jednak nie wszystko, co Mivart miał do powiedzenia na temat percepcji. Otóż w każdym spostrzeżeniu możemy rozróżnić dwa odrębne elementy, jeden zmysłowy, czyli subiektywny, drugi intelektualny, czyli obiektywny. Percepcja zatem okazuje się ujęciem istnienia rzeczy. Natura tej rzeczy ujawnia się nam poprzez doznane, w połączeniu z percepcją tej rzeczy, odczucia. 
Postrzeganie i odczuwanie są jedynie wstępem do prawdziwie wyjątkowych (na tle przyrody) zdolności człowieka. Potrafi on bowiem wyrażać znaczące sądy o rzeczywistości. Człowiek dokonuje tego dzięki (1) posiadaniu pojęcia ,,istoty” czy ,idei bycia” oraz (2) procesowi abstrahowania. Proces abstrahowania zatem stanowi drugi wyróżnik i niezbywalną, konieczną cechę natury ludzkiej. Abstrahowanie składa się z trzech czynności umysłowych:

(1) Pojmowanie przez jednoczenie albo syntezę odczuć (wytwarzaną przez jakości przedmiotu) jakiegoś rodzaju rzeczy; (2) umysłową analizę, albo oddzielenie jego jakości przez abstrakcję; i (3) znowuż syntezę umysłową jakości wcześniej wyabstrahowanych. ${ }^{12}$

Po rzuceniu światła na dwie niezbywalne cechy ludzkie, wyróżniające człowieka ze świata zwierzęcego, Mivart przechodzi do trzeciej, równie istotnej. Rozpoczyna od wskazania różnicy między odczuciami a ideami. Odczuwanie stanowi zdolność niższą, a pojmowanie idei wyższą. Odczucia są wrażeniami wywołanymi przez konkrety, natomiast idee są abstrakcyjne i uniwersalne. Mivart pisał:

Żadne natężenie wyobraźni nie jest $\mathrm{w}$ stanie kiedykolwiek przewyższyć doświadczenia zmysłowego, wszak z ideami jest całkiem odwrotnie. Nie tylko możemy pojmować, lecz także znamy doskonale tak naszą zdolność i naszą czynność widzenia. Jednak sama ta czynność nie była nigdy widziana i nie da się jej wyobrazić.

Odczucia ulegają połączeniu wedle swojego porządku w doświadczeniu lub wedle sąsiedztwa. Tymczasem idee mogą ulegać połączeniu wedle racjonalnego związku między nimi - logicznej zależności jednej od drugiej. ${ }^{13}$

\footnotetext{
${ }^{12}$ Mivart, „A Limit to Evolution...”, s. 302.

${ }^{13}$ Mivart, „A Limit to Evolution...”, s. 305.
} 
Człowiek jest w mocy zarówno odczuwać, jak i tworzyć idee abstrakcyjne, zwierzęta - jedynie to pierwsze. Różnica ta, według Mivarta, stanowi najważniejszą różnicę w całych badaniach nad wyjątkowością człowieka. I to ona właśnie jest tytułową granicą ewolucji. Człowiek wyraża idee abstrakcyjne, przyoblekając je w wypowiadane słowa. Zwierzęta natomiast pod tym względem są nieme. Oczywiście, niezaprzeczalne jest, że zwierzęta posiadają jakiś język, którym komunikują się między sobą, ale wyraża on jedynie emocje. Nie jest $\mathrm{w}$ mocy zamanifestować jakiejkolwiek idei uniwersalnej. W związku z tym Mivart podaje cztery powszechne reguły:

(1) Unikać mylącej skłonności naszych uczuć do zwierząt domowych. Ich właściciele stale podlegają pokusie, aby doszukiwać się znaczeń w działaniach tych zwierząt, na które nie ma rzeczywistego dowodu oraz by stronniczo brać niedoskonałe wplywy za rzeczywiste obserwacje.

(2) Unikać kuszącej skłonności do osądzania wszystkiego wedle własnej miary i wyobrażania sobie bez powodu ludzkich cech w obiektach, które nie są ludźmi. To jest ten błąd nadmiernej antropomorfizacji, przeciwko któremu oponenci wszystkich religii tak często nas ostrzegają.

(3) Nie przypuszczać działania nieznanych przyczyn, gdy znane przyczyny wystarczą do wyjaśnienia wszystkich zaobserwowanych faktów. To jest stara, dobrze znana reguła, zwana Brzytwą Ockhama: Entia non sunt multiplicanda praeter necessitatem. ${ }^{14}$

(4) Pamiętać, że jeżeli jakakolwiek przyczyna, jeśli w ogóle zaistniała, niechybnie powodowałaby pewne skutki - to nie wolno zakładać wystąpienia tej przyczyny, o ile nie da się wykryć takich skutków. ${ }^{15}$

Komentując te reguły, Mivart twierdził, że ostatnia zasada zmusza nas do zaprzeczenia, jakoby zwierzęta posiadały intelektualne zdolności. Gdyby bowiem je posiadały, zapewne bardzo szybko uświadomi-

\footnotetext{
${ }^{14}$ Łac. „bytów nie należy mnożyć ponad konieczność”.

${ }^{15}$ Mivart, „A Limit to Evolution...”, s. 310.
} 
łyby nas w tym, przyoblekając je w jakiś znaczący język, czy choćby gesty.

Zatem to właśnie zdolność abstrakcji i język, który wyraża idee abstrakcyjne, oraz dzięki któremu wypowiadamy znaczące sądy, stanowią tę nieprzekraczalną granicę ewolucji, która oddziela człowieka od zwierząt. Nie jest możliwe, aby umysł ludzki, który wytwarza wspomniane wyżej procesy, mógł wyewoluować $\mathrm{z}$ jakichkolwiek niższych stadiów. We wcześniejszej pracy, The Origin of Human Reason, Mivart jednoznacznie wskazywał, że badania nad faktem życia ludzkiego skłaniają nas do przekonania, że:

[...] nasza umysłowa i wolicjonalna natura jest istotnie różna od [natury] jedynie zwierzęcej [...].

Każda istota ludzka jest prawdziwą jednością, która posiada równocześnie zdolności dwóch natur - jedną zwierzęcą i drugą racjonalną, obie grupy zdolności współpracują ze sobą w całym życiu psychicznym każdej jednostki. Zatem, w celu badania nie możemy oddzielić naszego umysłu od naszej aktywności zmysłowej [...]. Jednakże możemy wystarczająco oddzielić jakości każdej z tych dwóch grup, by uświadomić sobie wielką różnicę, jaka zachodzi między nimi $[\ldots]$.

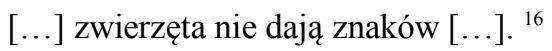

Ta wyjątkowość konstytucji człowieka skłoniła Mivarta do zanegowania stosowalności mechanizmu doboru naturalnego w kwestii wytworzenia ludzkich zdolności umysłowych. Oczywiście, to bynajmniej nie znaczy, że Mivart całkowicie negował teorię Darwina. W On the Genesis of Species pisał, że teoria ewolucji Darwina powinna być tylko tłem dla dalszych rozważań. Dusza i umysł człowieka nie powstały drogą ewolucyjną, lecz zostały w nadprzyrodzony sposób stworzone. Autor powoływał się w pracy na filozoficzne poglądy św.

\footnotetext{
${ }^{16}$ Mivart, The Origin of Human Reason..., s. 5-7. Ludzie przeciwnie, mają zdolność znakotwórczą; Mivart przez znak rozumie zewnętrzną manifestację jakiejś idei lub połączenia idei.
} 
Augustyna, św. Tomasza i innych filozofów klasycznych, rozpatrujących problem pochodzenia człowieka. Odwołania do filozofii niech nie dziwią, bowiem Mivart oprócz tego, że był biologiem, był też filozofem. W tej ostatniej roli skłaniał się ku neoscholastyce, sprzeciwiając się doktrynom postkartezjańskim. Rozważał między innymi problem kreacji. W On the Genesis of Species wyróżnił trzy znaczenia terminu ,stworzenie":

W najściślejszym i najwyższym sensie „stworzenie” stanowi absolutne zapoczątkowanie wszechrzeczy przez Boga, bez wprzód istniejącego pierwotnego środka $\mathrm{i}$ tworzywa, co jest aktem nadprzyrodzonym.

W drugim, niższym sensie „stworzenie” stanowi utworzenie jakiejkolwiek rzeczy wtórnie. To znaczy, że preegzystująca materia została stworzona wraz z potencjalnością, pozwalającą na to, by w odpowiednich warunkach wyłoniła z siebie wszelkie formy, które potem będzie przyjmować. Ta zdolność została [jej] nadana przez Boga najpierw. Stanowi to naturalna aktywność Boga w świecie fizycznym, w odróżnieniu od Jego aktywności bezpośredniej, lub, jak można tu rzec, nadprzyrodzonej.

W trzecim sensie słowo „stworzenie” mniej lub bardziej odpowiednio stosuje się do konstrukcji jakiegokolwiek złożenia albo stanu przez obdarzoną wolą i samoświadomą istotę, czyniącą użytek ze zdolności i praw nadanych przez Boga, tak jak mówimy o człowieku, że tworzy muzeum czy „swój własny los” i tak dalej. Takie działanie stworzonej, świadomej inteligencji jest czysto naturalne, ale przekracza działanie fizyczne, toteż można je określić wygodnym mianem ponadfizycznego. ${ }^{17}$

W tymże dziele znajduje się fragment, który wyrażając jądro filozofii Mivarta, streszcza zarazem jego teistyczny ewolucjonizm:

[...] jeżeli można dostrzec inteligencję kierującą ewolucją każdego systemu światów i wzrostem każdego źdźbła trawy - to niewątpliwie ten doniosły rezultat harmonizuje z nauką wiary, wedle której w porządku naturalnym Bóg działa współuczestnicząc w prawach materialnego wszechświata, które nie tylko zosta-

\footnotetext{
${ }^{17}$ Mivart, On the Genesis of the Species..., s. 290-291.
} 
ły ustanowione wedle Jego woli, ale są podtrzymywane dzięki Jego współdziałaniu; zaś my w ten sposób zdolni jesteśmy do rozpoznania w naturalnym porządku, choćby niejasno, Boskiego Autora przyrody - Tego, w którym ,żyjemy, poruszamy się i jesteśmy". ${ }^{18}$

Z kolei w artykule „Modern Catholics and Scientific Freedom”, jednym z tych, które spowodowały obłożenie go ekskomuniką, chciał Mivart wykazać zgodność między rozwiniętą nauką a ortodoksyjnym chrześcijaństwem. Nazywał siebie „lojalnym synem Kościoła”, ${ }^{19}$ ale jak pisał - jego rolą nie była egzegeza, bowiem nie posiadał do tego odpowiednich umiejętności, a tylko osądzenie przedmiotu wiary przy pomocy nauki. ${ }^{20}$

Jak wynika z tej skróconej prezentacji sylwetki uczonego, Mivart był ważną postacią $\mathrm{w}$ dziewiętnastowiecznym przyrodoznawstwie, dotychczas jednak żadna jego praca nie została przetłumaczona na język polski. Co więcej, trudno znaleźć jakąś wzmiankę o nim w polskich encyklopediach.

Justyna Kroczak

${ }^{18}$ Mivart, On the Genesis of the Species..., s. 324.

${ }^{19}$ St. George Jackson Mivart, „Modern Catholics and Scientific Freedom”, Nineteenth Century, June 1885, vol. XVIII, no. 101, s. 32.

${ }^{20}$ Mivart, ,Modern Catholics...”, s. 43. 